\title{
Indigenous Knowledge and Intellectual Property: Drug Research and Development in Contemporary Context
}

\section{Janet K Brewer ${ }^{*}$}

Institute for Indigenous People's Rights, Lewes, DE, USA

"Corresponding author: Janet K Brewer, Director, Institute for Indigenous People's Rights, Lewes, DE, USA, Tel: 2128542479; E-mail: janetkbrewer@cs.com

Rec date: March 21, 2014; Acc date: May 28, 2014; Pub date: June 06, 2014

Copyright: () 2014 Brewer JK. This is an open-access article distributed under the terms of the Creative Commons Attribution License, which permits unrestricted use, distribution, and reproduction in any medium, provided the original author and source are credited.

\section{Indigenous Knowledge}

Indigenous knowledge refers to the knowledge of naturally available resources and existing practices among community groups that have long-contributed a particular benefit for the sustenance of the group, particularly within the health care context. Indigenous knowledge reaches beyond the use of plants, encompassing empirical observations and their interaction with community groups, and a system of classification and careful management of the resource. Indigenous knowledge often includes a belief system in spiritual entities and their relationship with the group. Thus, rather than a detailed compilation of information about plants, it becomes a worldview-what we understand and study as "culture". For most indigenous peoples, good health represents a state of equilibrium among spiritual, communal and individual; it is not merely the absence of disease [1-3]

Indigenous knowledge is a very important component of pharmaceutical research and development for a number of reasons. Primarily, pharmaceutical researchers seek to isolate the active compounds within plants and other natural resources used by indigenous peoples medicinally. By identifying compounds embedded in the large body of cultural knowledge, practices, and beliefs of an indigenous group which have proven effective, at least anecdotally, for centuries, drug researchers can greatly shorten the long and winding road toward the development of an efficacious and lucrative pharmaceutical compound $[4,5]$.

Historically, research conducted among indigenous groups has proven inappropriate secondary to the use of culturally insensitive research designs and methodologies that fail to appreciate the beliefs, customs, and property rights of indigenous peoples. Additionally, history is replete with instances of lack of informed consent with respect to indigenous groups. Finally, there have been examples of outright violations of trust upon the part of Western researchers. For example, the Havasupai medical genetics case in Arizona aptly illustrates the range of problems that exist when Western researchers involve indigenous groups in research. In this study, blood was collected from a particular tribe purportedly for the investigation of the molecular underpinnings of diabetes, and for this reason, was granted approval by the tribe. However, ultimately, the samples were used for the study of numerous mental illnesses, including schizophrenia, leading to stigmatization of this socially-identifiable group [6-9].

Because of this history of the interaction between Western researchers and indigenous groups which is burgeoning with examples of bioethical violations, indigenous groups are entitled to special consideration and protection in the context of research. More recently, researchers have begun to expose the core assumptions of Western researchers and the manner in which this research fuels oppression and exploitation. For this reason, greater consideration has been given
non-Western cultures participating in socially-identifiable research with respect to the recognition that the "group" and not just the "individual," as in Western culture, are paramount to the survival and well-being of the non-Western cultural group. Indeed, given the negative impact of improper research with indigenous communities, the more ethically sound approach has been based on community consultation, and research methodologies that acknowledge indigenous knowledge, thus ensuring that the research is both culturally appropriate and rigorous in design [10].

This is why emerging partnerships among indigenous groups and Western researchers in some contemporary research deserve careful scrutiny, and, perhaps, some applause. In very recent years, the research and development landscape has witnessed a positive shift towards collaborative researches efforts with indigenous communities in which all participants negotiate and benefit. The Convention on Biological Diversity and the off-spinning research guidelines regulated by this instrument have exerted a far-reaching influence. In short, indigenous peoples are gaining recognition for their knowledge and are striving for a more self-determined approach to the management of their intellectual property. A key example is the Northern Kaanju tribe of Australia which initiated research with Westerners to study the pharmacological properties of plants used in the traditional medicine of their ancestors. In this model, medicinal plant research relying on local indigenous knowledge was performed in collaboration with University-based researchers in the joint investigation of medicine. This model is in stark contrast to the historic "stakeholders" and "informants" model leading to exploitation of the indigenous group that has been used $[11,12]$.

The outcomes of this scientific research where indigenous people actively initiated, participated and steered the medicinal plant research produced products with commercial value.

Furthermore, this collaborative research model has resulted in the filing for patent protection of intellectual property in association with novel compounds and extracts. The model was conceptualized and carried out with development and intellectual property considerations all around. This indigenous-driven medicinal plant research project proactively examined ways to develop medicinal plant resources embedded within indigenous knowledge while asserting intellectual property rights, as well as to sustain its culture. Projects similar to these may lead to the development of novel plant-based commercial products which will fuel free enterprise and intellectual property rights among indigenous groups. Increasingly, we may see a shift toward indigenous-driven, more self-determined approaches to the management of knowledge and medicinal resources [12]. 
Citation: Brewer JK (2014) Indigenous Knowledge and Intellectual Property: Drug Research and Development in Contemporary Context. Intel Prop Rights 2: 120. doi:10.4172/2375-4516.1000120

Page 2 of 2

\section{References}

1. Bristow F, Stephens C, Nettleton C (2003) Utz W'achil: Health and wellbeing among indigenous peoples. London: Health Unlimited. London School of Hygiene and Tropical Medicine.

2. Browner CH, Demontellano BRO, Rubel AJ (1988) A methodology for cross-cultural ethnomedical research. Current Anthropology 29: 681-702.

3. Claudie DJ, Semple SJ, Smith NM, Simpson BS (2012) Ancient but new. Developing locally-driven enterprises based on traditional medicines in "Kuuku I'yu" (Northern Kaanju homelands, Cape York, Queensland, Australia). In: Drahos P, Frankel S, editors. Indigenous Peoples' Innovation: IP Pathways to development. Canberra: ANU epress.

4. Cochran PAL, Marshall CA, Garcia-Downing C, Kendall E, Cook D et al. (2008) Indigenous ways of knowing: Implications for participatory research and community. American Journal of Public Health 98: 22-27.

5. McDade T, Reyes-García V, Leonard W, Tanner S, Huanca T (2007) Maternal ethnobotanical knowledge is associated with multiple measures of child health in the Bolivian Amazon. Proceedings of the National Academy of Sciences of the United States of America 104: 6134-6139.

6. Posey DA (2002) Commodification of the sacred through intellectual property rights. Jof Ethnopharmacol 83: 3-12.
7. Reyes-García V (2010) The relevance of traditional knowledge systems for ethnopharmacological research: Theoretical and methodological contributions. Journal of Ethnobiology and Ethnomedicine 6: 32.

8. Reyes-Garcia V, McDade T, Vadez V, Huanca T, Leonard WR et al (2008) Non-market returns to traditional human capital: Nutritional status and traditional knowledge in a native Amazonian society. Journal of Development Studies 44: 217-232.

9. Simpson BS, Claudie DJ, Smith NM, McKinnon RA, Semple SJ (2013) Learning from both sides: Experiences and opportunities in the investigation of Australian aboriginal medicinal plants. J Pharm Pharm Sci 16: 259-271.

10. Smith BR (2007) 'Indigenous' and 'Scientific' knowledge in Central Cape York Peninsula. In: Sillitoe, P. (Ed.) Local science vs global science: Approaches to indigenous knowledge in international development. Berghahn Books.

11. Soejarto DD, Fong HHS, Tan GT, Zhang HJ, Ma CY et al. (2005) Ethnobotany/ethnopharmacology and mass bioprospecting: Issues on intellectual property and benefit-sharing. J Ethnopharmacol 100: 15-22.

12. Tan A, Sze D (2008) Indigenous herbs and cancer. J Complement Med 7: 48-50. 